\title{
MOTIVATIONS AND THE EFFECTS OF VALUES RELATING TO THE
} CONSUMPTION OF BIO FOODS

\author{
ÉVA GERGELY, BERNADETT SZABó \\ Faculty of Applied Economics and Rural Development, University of Debrecen \\ Böszörményi St. 138, 4032 Debrecen, Hungary \\ gergelyeva@agr.unideb.hu
}

\begin{abstract}
The aim of the study is to examine the psychological and demographic factors influencing the consumption of bio foods. The motivations for consuming bio foods and the effect of values were investigated among students. The respondents consider bio foods as healthier, of better quality, more environmental conscious but more expensive than traditional foods. All in all the respondents have positive attitudes relating to bio foods. Consuming bio foods just for fashion and its prestige is not typical among the consumers. The blocking factors of consumption include the price of bio foods and disbelief in the production way. On the basis of the Rokeach Value Survey traditional values such as self-respect, sense of accomplishment and inner harmony are the most important factors for the respondents. Respondents living in independent households with children find the comfortable, exciting and joyful life and even the social recognition important. As in the values of the respondents family has an outstanding role, this could be utilized during marketing communications.
\end{abstract}

Keywords: bio food, motivation, value, terminal value

\section{INTRODUCTION}

Nowadays stimulating the consumption of bio foods is a highlighted topic from the aspects of health and environment consciousness (TóTH, 2009). Only a narrow social layer consumes these kinds of foodstuffs regularly, but their consumption reflects an increasing tendency (GYARMATI, 2004). The group of young consumers may play a relevant role in the future as they might have heard about bio foods since their early childhood. It is obvious that it is easier to convince them as their value is still under formation. The contribution of the youth is very important regarding the future, their consumption will influence their environment in a longer term, and they are responsible for the sustainability.

This study shows several results of a greater research. The whole research investigates the motivations, attitudes, beliefs relating to bio foods, environment and health consciousness and willingness for innovation among students, supplementing with value research. This present study focuses on the consumption of bio foods of the students asked in the terms of value.

\section{The Consumption Tendency of Bio Foods}

The ratio of the territory of controlled ecological farming is $2 \%$ of the agricultural land in Hungary, which equals with 119 thousand hectares (NVS, 2012; RoszIK, 2013). Favourable tendency may be expected in the following years, as in the Ecological Farming Program in the National Rural Strategy (NVS) for the period of 2012 to 2020, the planned size of ecological farming is 350 thousand hectares (NVS, 2012). The ratio of the produced bio foods is growing higher, but more than $80 \%$ of it is exported. Its reason is the narrow consuming layer (TÓTH, 2009). The online survey of NIELSEN MARKET RESEARCH COMPANY (2010) on purchasing bio foods is the biggest research of such a kind in the world. They carried out a survey in 54 countries, even in Hungary. They concluded that 
every eighth Hungarian consumer (13\%) buys bio foods, while this ratio in Europe is 35\%. According to their results $84 \%$ of the asked Hungarian bio food consumers think that bio foods are healthier, $70 \%$ think that they avoid pesticides and other poisons by choosing bio foods. More than $91 \%$ of the purchasers are modified by the price when buying. One third of the respondents do not buy bio foods; the majority of those who buy bio foods, buy them monthly and weekly (То́тH, 2009). On the basis of data of a previous examination $35 \%$ of the respondents consume bio foods at least on a monthly basis, the regular consumers take up only $20 \%$ of all of the respondents (LENGYEL, 2008). Regarding the consumption of bio foods it is relevant that a positive correlation was revealed between the attitudes towards the environment and the environmental conscious behavior (CORRALIZA AND BERENGUER, 2000; COTTRELL, 2003).

\section{Examining the Major Factors Influencing the Consuming Behavior}

The consumer behavior is influenced by cultural and social factors as well as personal and psychological features (KOTLER, 2001; KOTLER AND KELLER, 2006). The culture basically determines people's manners, demand and behavior. The values express the fact that what is considered as important, good or bad by a given culture.

In connection with social factors on the basis of HORVÁTH AND BODNÁR (2009)'s researches regarding rural areas the employment and profit condition, the educational level of the rural population are lagged behind the national average. Furthermore there is a significant setback relating to the ratio of those who graduated from university or college or high school. Due to the lack of proper psychological and demographical conditions there are few opportunities for developing creativity, thus choosing a more health and environmental conscious life and consuming bio foods.

Personal feature may base a further motivating factor during consumption. In this case the age and family life cycle are focused on as there are life periods when consuming bio foods may come forward for the sake of health safety. From the aspect of bio food consumption the fact is important that the consumer lives with parents in one household or lives in a separate household, as this may affect the influence on making decisions relating to the household. It is reasonable to create a third category as well, which is a household being independent from parents, but not fully independent from the family house (MÁDER, 2009; VASKOVICS, 2000). The young adults in the postadolescent period (below 30 years of age) are not fully independent from the family house (MÁDER, 2009).

One of the most determinant elements of the consumers' behavior is the individual value. The values are permanent conceptions or convictions and relate to the desired behaving way. The values prevail in different situations and have a leading role in the evaluation of the happenings. On the other hand the values are organized according to a relative importance (HOFMEISTER-TóTH ET AL., 2006). Values have motivational tasks as well, as they stimulate to reach objectives considered as being appropriate by us. ROKEACH (1968) classifies two sets of values, such as the terminal values and the instrumental values. The terminal values are individual or social-centered ones. The instrumental values may be classified as moral or competence values. People have much less terminal values than instrumental values. The introduced classification of values was taken into consideration during our investigation.

\section{Objectives}

The objective of the study is to examine the previously mentioned factors influencing the consumption of bio foods. The investigation of cultural, psychological and personal factors are detailed, furthermore, motivations for consuming bio foods, attitudes and terminal values are examined. Regarding the reason for consuming bio foods we suppose a 
difference between students having a joint household with parents and students being independent from parents but not having independent households. It is expected that the general attitudes on bio foods of students having children and independent households are different compared to students under other conditions of life. Our objective relating to the value is the following: terminal value examination is carried out, where the differences are looked for in case of students having children and independent households, student with joint households with the parents and students having independent households.

\section{MATERIAL AND METHOD}

Data gathering happened with the help of an online survey. The questionnaire used for the whole research starts with demographic questions, then deals with consuming habits of bio foods, it contains the "New Environmental Paradigm" scale as well and the terminal values determined by Rokeach. Only parts are detailed, which are dealt with in the present study. Demographic questions relate to sex, age, education, circumstances, number of children of the interviewees and the age of children. The second part of the questionnaire is in connection with attitudes, consuming habits and beliefs relating to bio foods. The third part is the "New Environmental Paradigm" (NEP) scale. The fourth component of the survey contains the terminal values determined by Rokeach. The task of the interviewees was to grade these values by the help of a seven graded scale accordingly to what rate they are important for them. Eighteen terminal values are being evaluated describing the goals that a person wishes to achieve during the lifetime and considers them as being appropriate.

The number of elements in the survey was 312 persons. The respondents of the questionnaire were all students at the University of Debrecen in the Faculty of Arts and Humanities and in the Faculty of Applied Economics and Rural Development. 217 of them were full-time students, 94 students were correspondence (part-time) students ( 2 of them did not respond). 253 women and 59 men (1 man did not respond) answered to the questions. The youngest respondent was 18 years old, while the oldest answerer was 53 years old. The age does not follow a normal distribution (Kolmogorov-Szmirnov test: $\mathrm{D}=0.233, \mathrm{p}<0.001$ ), its median is 22 . Regarding their circumstances 162 persons have joint households with parents, 73 persons have households being independent from parents and 77 persons ( 1 person did not answer) have households being partly independent from the family house. Relating to the number of children it turned out that 278 respondents do not have any children, 11 persons have one child, 21 answerers have tow children, 2 persons have three children and 1 respondent has four children.

\section{RESULTS}

\section{Attitudes and Consuming Habits Relating to Bio Foods}

Surveying the attitudes of the respondents in connection with bio foods happened comparing them to traditional foods in parallel. The results of the examinations strengthen the relevance literature data (FÜREDINÉ KOVÁCS ET AL., 2006; TÓTH, 2009) by which the respondents find bio food healthier, having better quality, more environmental friendly and tastier than conventional foods. Even the present research reflects the fact (similarly to the researches of GYARMATI, 2004; SZENTE, 2006) that the interviewees considered bio foods as more expensive. The respondents have positive attitudes relating to bio foods.

The questionnaire dealt with even the causes and motivations of consuming bio foods. The respondents evaluated the potential answers by the help of a scale ranging from 1 to 7 on 
the basis that to what ratio they were typical. As the variable does not reflect a normal distribution, the median is used as an average and the results are introduced item by item (Figure 1). The most important motivations for consuming bio foods are saving the health, avoiding harmful effects of traditional foods and saving the environment.

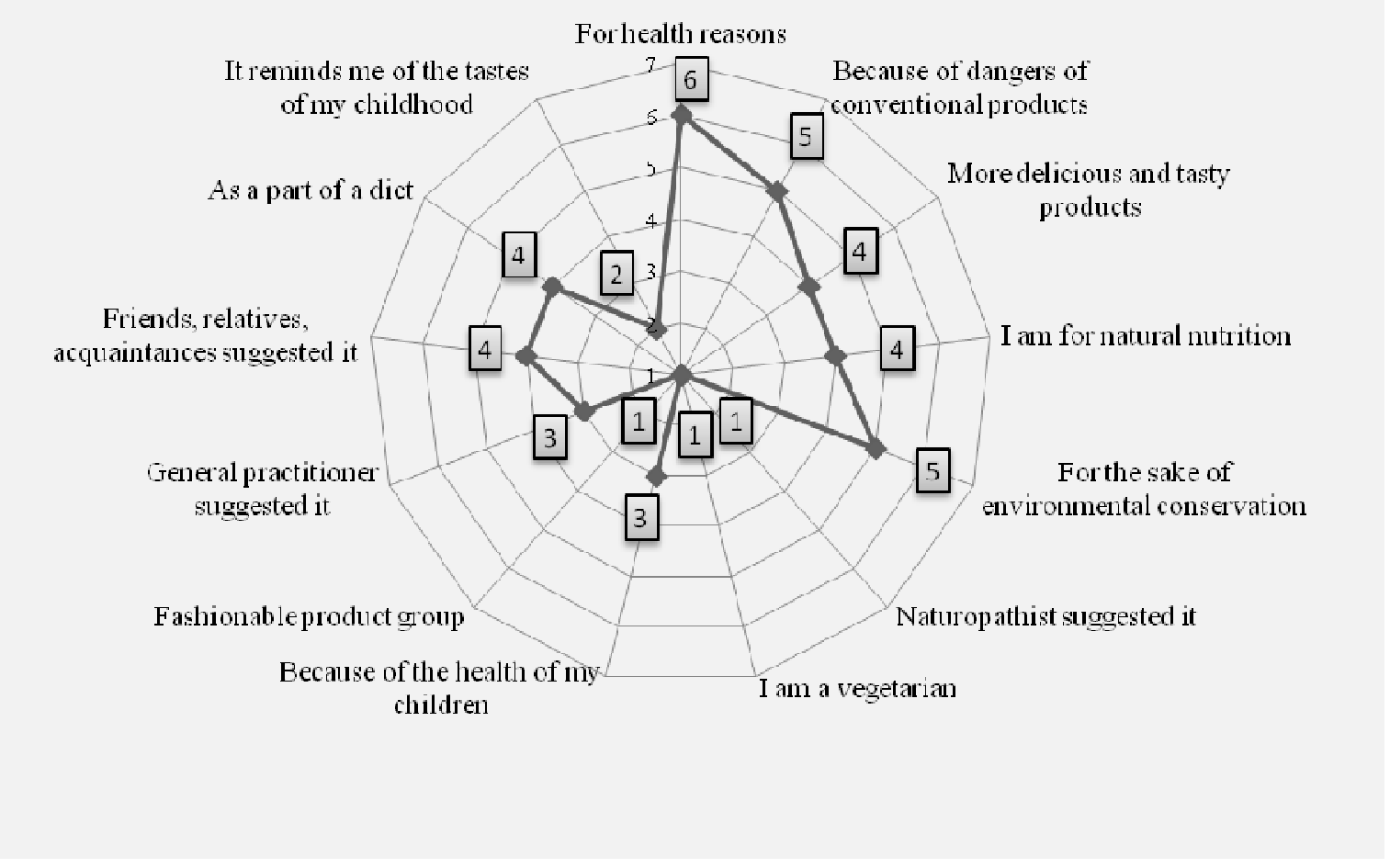

Figure 1. The Medians of Motivations Relating to Consuming Bio Foods

Source: Own research, 2013

It must be highlighted that consuming bio foods just for fashion and its prestige is not typical $(\mathrm{M}=1)$ on the basis of the self-assessment. It seems that other factors motivate the consumption of bio foods. In case of respondents having children and independent household the motivating factor called "because of the health of my children" results a significant difference ( $\mathrm{W}=7236, \mathrm{p}-<=0,005)$, respondents having children and independent households are more motivated in purchasing bio foods for the sake of the health of their children $(\mathrm{M}=4)$ than those belonging to other categories $(\mathrm{M}=2$ on the basis of MannWhitney test). The biggest blocking factor of the consumption is the price of the bio foods $(\mathrm{M}=6)$, a moderate blocking factor is the fact that respondents do not believe in the production way $(M=4)$ and there are few bio shops operating $(M=4)$.

\section{Investigations in Connection With Terminal Values}

The medians of the 18 terminal values determined by Rokeach are illustrated in Figure 2. We concluded that to the respondents' mind all of the given terminal values are more important than a moderate evaluation. On the basis of the value survey it turned out that traditional values (family security, happiness, friendship) are the most important values for the answerers. 


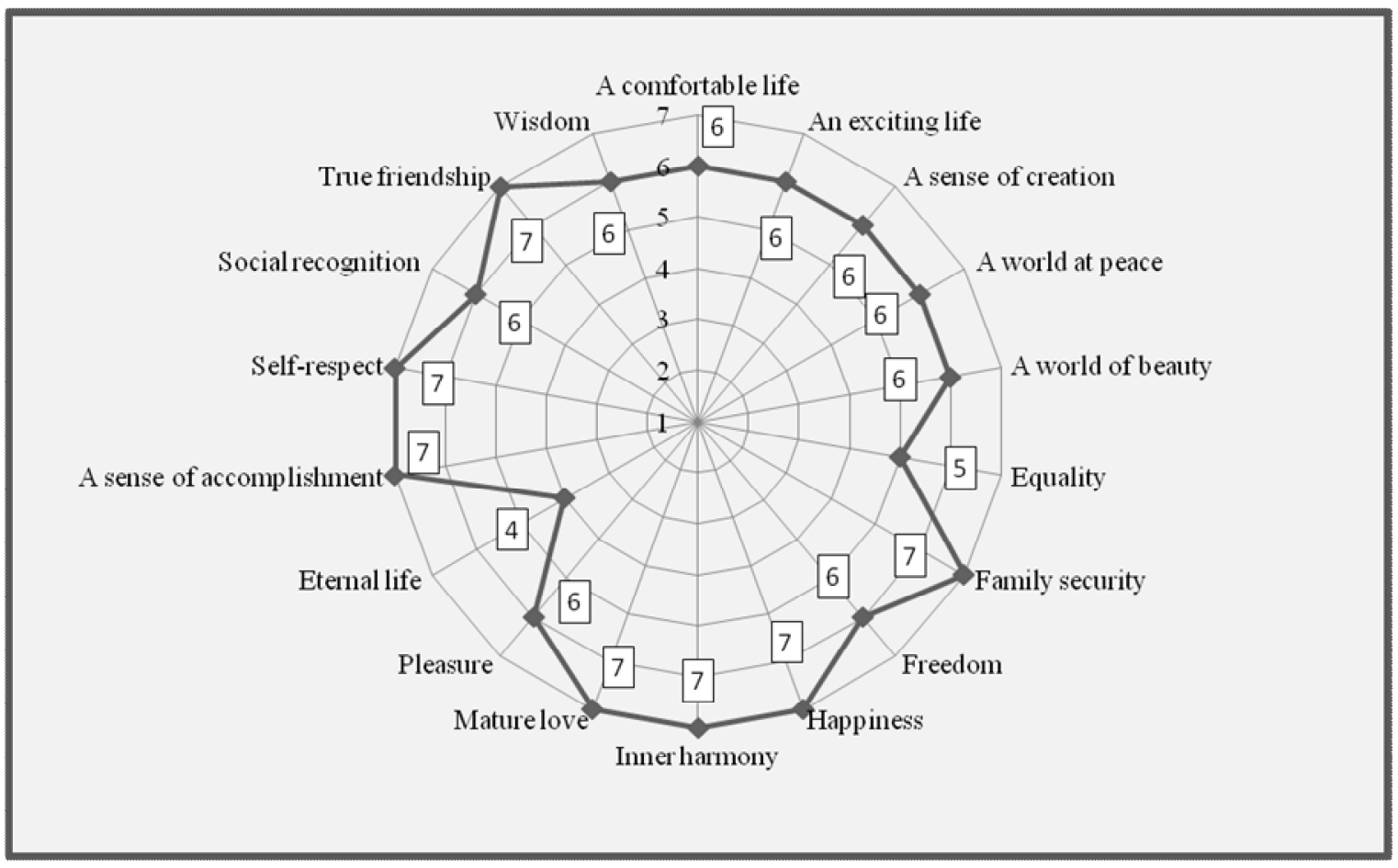

Figure 2. The Medians of Terminal Values of the Respondents Source: Own research, 2013

These pieces of information may be utilized for increasing the consumption of bio foods in a way that during the marketing communication the outstanding relevance of the family life should be taken into consideration. The long-term advantageous effects of bio foods may be demonstrated in this context as well, as they understand that the consumption of bio foods has a highlighted significance for the sake of the health of the family.

In the sample there are 33 persons who have independent households and children and 280 persons constitute the other category. The two categories were compared by MannWhitney test from the aspects of terminal values. Utilizing Rokeach survey we suppose that students having children and independent households, students having joint households with parents and students having independent households from parents prefer other terminal values.

Although those who live in independent households with children $(M=5)$ find the comfortable life important but not such a degree than respondents belonging to other categories $(\mathrm{M}=6)$ (Mann-Whitney test: $\mathrm{W}=5853, \mathrm{p}<=0,009)$. The exciting life is more important for persons living in jointly households with parents and those who are partly independent from parents $(M=6)$ than for answerers in the other group $(M=5$, MannWhitney test: $\mathrm{W}=6369, \mathrm{p}<=0,001$ ). A world at peace (no war) is more important for persons living in independent households with children $(M=7)$ regardless the fact that those belonging to the other category find it important as well $(M=6)$. Regarding pleasure (funny life) differences were revealed in terms of the circumstances (Mann-Whitney test: $\mathrm{W}=6626, \mathrm{p}<=0,001)$. The respondents of every category judged it important but it is a more important factor for those living together with parents and those who have partly independent households $(M=7)$ than in case of persons running separate households $(\mathrm{M}=5)$. The social recognition (respect, admiration) (Mann-Whitney test: $\mathrm{W}=5609,5, \mathrm{p}$ 
$<=0,038$ ) is also important to respondents running separate households with children $(\mathrm{M}=5)$, though it is more relevant for those belonging to the other category $(\mathrm{M}=6)$.

The gained results may help in motivating individuals for consuming bio foods as healthy diet motivates the already existing consumers, thus it is worth aiming at increasing the consumption from another aspect. For students living together with parents and those having partly independent households from parents campaigns would be motivating factors which would connect bio food consumption to exciting, active and funny life. The social recognition, the facts of respect and admiration should be connected to the consumption of bio foods for those having separate households with children.

\section{CONCLUSIONS}

The topic of this study was to examine the psychological and demographic factors influencing the consumption of bio foods through a survey. The questionnaire dealt with the motivations and attitudes relating to bio food consumption and even the values of the respondents were examined. During the survey altogether 312 students were asked at the University of Debrecen. The respondents considered bio foods as healthier, of better quality, more environmental conscious and tastier than traditional foods. The respondents have positive attitudes relating to bio foods. It must be highlighted that consuming bio foods just for fashion and its prestige is not typical. The biggest blocking factor of the consumption is the price of the bio foods, a moderate blocking factor is the fact that respondents do not believe in the production way and there are few bio shops operating. On the basis of the value survey traditional values such as self-respect, sense of accomplishment and inner harmony are the most important factors for the respondents. Although those who live in independent households with children find the comfortable, exciting and joyful life and even the social recognition important but not such a degree than respondents living together with parents or living separately but being partly independent from them. As in the values of the respondents family has an outstanding role, this could be utilized during the marketing communication and emphasized that by consuming bio foods they can provide a healthier life for their family.

\section{REFERENCES}

Corraliza, J. A., Berenguer, J. (2000): „Environmental Values, Beliefs, and Actions. A Situational Approach", Environment and Behavior 32(6): 832-848.

COTTRELL, S. P. (2003): „Influence of Sociodemographics and Environmental Attitudes on General responsible Environmental Behavior Among Recreational Boaters", Environment and Behavior 35(3): 347-375.

FÜrediné KovÁCs. A., Gelencsér M., Miklay G. (2006): A magyar ökoélelmiszerek iránti kereslet az ökopiacokon és a szupermarketekben vásárlók körében, A Magyar Biokultúra Szövetség 2006. évi fogyasztói megkérdezése

GYARMATI G. (2004): A hazai biolisztek fogyasztásának időbeli és területi sajátosságai, Pécsi Tudományegyetem Közgazdaságtudományi Kara, Regionális Politika és Gazdaságtan Doktori Iskola, Évkönyv 2004. 1. kötet, pp. 176-182

HofMEISTER-TÓTH Á., SiMON J., BÓDI E. (2006): A fogyasztók társadalmi felelősségének kérdései, Konferencia előadás, Innováció, társadalmi felelősség, fenntartható fejlődés marketing megközelítésben, a Magyar Marketing Szövetség - Marketing Oktatok Klubjának 12. Országos Konferenciája, Budapest, 2006. augusztus 24-25 
HoRVÁTH J., BODNÁR K. (2009): Vidékfejlesztési lehetőségek Kakasszéken és környékén. Jelenkori Társadalmi és Gazdasági Folyamatok 4(3-4): 26-30.

KotLer, P. (2001): Marketing menedzsment. Müszaki Könyvkiadó, Budapest. 875 p.

Kotler, P., Keller, K. L. (2006): Marketing-menedzsment, Budapest: Akadémia Kiadó

LENGYEL P. (2008): „Biomarketing” A bioélelmiszer-piac bemutatása, a kategória iránti kereslet alakulása a fiatal felnőttek körében, Budapesti Gazdasági Főiskola, Szakdolgozat MÁDER, M.P. (2009): „A szülőktől való elszakadási dimenziók mentén létrejött alcsoportok". Új Ifjúsági Szemle, Ifjúság és Környezet, 2009/tél, 109-114.

Downloaded: http://www.uisz.hu/archivum/uisz_25_mader.pdf

NiELSEN MARKET RESEARCH COMPANY (2010): Bioterméket csak minden nyolcadik magyar szokott vásárolni. Downloaded: http://hu.nielsen.com/site/20100819.shtml

NVS (2012): Nemzeti Vidékstratégia 2012-2020, „a magyar vidék alkotmánya”, Vidékfejlesztési Minisztérium, 76, 124, Downloaded:

http://www.kormany.hu/download/8/ff/70000/Nemzeti\%20Vid\%C3\%A9kstrat\%C3\%A9gi a.pdf

RoKeAch, M. (1968): Beliefs, Attitudes and Values. Jossey Bass, San Francisco. 230 p.

RoszIK, P. (2013): Jelentés a Biokontroll Hungária Nonprofit Kft 2012. évi tevékenységéről. Biokontroll Hungária Nonprofit Kft., Budapest, 14 p.

SzENTE, V. (2006): Tendenciák az ökoélelmiszerek fogyasztásában és értékesítésében. Élelmiszer, Táplálkozás és Marketing 3: 31-36.

TóTH H. (2009): Innováció az életmódban - avagy a hosszú élet titka. ECOSTAT Kormányzati Gazdaság- és Társadalom-stratégiai Kutató Intézet Műhely. 2009 július VASKOVICS L. (2000): A posztadoleszcencia szociológiai elmélete. Szociológiai Szemle 20(4): 3-20. 